\title{
The 1988 Black Sea Oceanographic EXPEDITION: OverviEW AND NEW DiscoverIES
}

\section{By James W. Murray and Erol Izdar}

$\mathrm{T}$ HE 1988 Black Sea Oceanographic Expedition was conducted on the R/V Knorr during four months of the spring and summer of 1988. This expedition consisted of five cruises organized by U.S. and Turkish scientists to study all major aspects of the oceanography of this unique anoxic environment. One of the most interesting new results was that unexpected changes had occurred in the oxic/ anoxic interface.

Anoxic basins have always intrigued oceanographers. They are attracted by the extreme conditions caused by the absence of oxygen and the extensive formation of reduced substances such as hydrogen sulfide. The boundary between the oxygen and sulfide-rich waters is a useful site for studying the rates of oxidation and reduction reactions under readily accessible in situ conditions. An analogy can be made to the less accessible and finer scale oxic/ anoxic interface in marine sediments. There is a paleo-oceanographic connection as well, because it is necessary to understand present-day anoxic environments if we are to understand anoxic conditions in the oceans past. Finally, we can point to our increasing need to understand global ocean fluxes and the effect that anoxic/sulfide environments have on those fluxes and their preservation in the geological record.

The Black Sea is the definitive anoxic basin. A Coastal Zone Color Scanner pigment image of the western basin is shown in Fig. 1 (p. 16), showing that the chlorophyll and particulate matter concentrations are highest along the northwest shelf (NWS) region. The Black Sea is the world's largest permanently anoxic basin, covering about $508.000 \mathrm{~km}^{2}$. It is bordered by four countries: Turkey, the Soviet Union, Rumania and Bulgaria (Fig. 2, p. 17). Below approximately $100 \mathrm{~m}$, it is filled with anoxic waters that contain hydrogen sulfide. The anoxic conditions are the result of a permanent halocline, which separates higher salinity, denser deep waters of Mediterranean origin from lower salinity, lower density surface waters diluted by river runoff. The halocline limits strong vertical mixing to the surface layer, and thus the deep waters are stagnant and devoid of oxygen.

James W. Murray, School of Oceanography. University of Washington, Seattle, WA 98195; and Erol İzdar, Dokuz. Eylül Üniversity, Institute of Marine Science and Technology, P.O. 478, 35213 İzmir, Turkey.
Unlike other stagnant basins that are intermittently anoxic on time scales of years to decades, the Black Sea provides a quasi-steady state system with an anoxic deep water replacement time on the order of 2,000 years.

There have been periodic cruises by U.S. research vessels and U.S. scientists to the Black Sea. International cruises by the R.V. Atlantis II in 1969 and the $\mathrm{R} / \mathrm{V}$ Chain in 1975 provided most of the data base that the 1988 expedition used for planning purposes. In the thirteen years since the last major U.S. cruise to the Black Sea, major advances have been made in the conceptual models and sampling, analytical and experimental techniques that can be applied to anoxic basins.

In June, 1987 a meeting of the U.S. and Turkish coordinating committees (Table 1, p. 21) was held in Izmir, Turkey (hosted by Professor Erol İzdar of Dokuz Eylül Üniversity) to discuss how modern oceanographic approaches could be applied to the intriguing problems of anoxic basins. Out of this meeting grew the 1988 expedition. A total of 111 scientists from 39 universities and institutions participated in the five cruises that were conducted from April 16 to July 29, 1988. Each cruise had its own emphasis; a summary of the scientific projects conducted is shown in Table 2 (p. 21). In a broad sense, the objective of Cruise 1 was to study the sedimentary evolution of the Black Sea by examining particle fluxes and sediment cores. Cruise 2 focused on the microbiology of the carbon, nitrogen and sulfur cycles. The emphasis of Cruise 3 was the cycling of trace elements and nutrients across the anoxic interface. Cruise 4 had two objectives. The first was to determine the circulation of the Black Sea using oceanographic tracers. The second was to study sedimentary geochemistry and depositional history. A collaborative study of nitrogen and carbon cycle distributions and microbiology was conducted on Cruise 5. At the conclusion of the Black Sea Expedition, two days of water column and sediment sampling was conducted in the Sea of Marmara under the direction of Turkish scientists. All cruises benefitted from high quality conductivity, temperature and depth data obtained by George White and co-workers (University of Washington). Lou Codispoti and Gernot Friederich (Monterey Bay Aquarium Re-
The Black Sea

is the world's largest

permanently anoxic

basin, covering about

$508,000 \mathrm{~km}^{2}$. 
The most exciting

of these changes

is that the first

appearance of sulfide

has moved upward in

the water column and

that a sub-oxic zone

$\left(0_{2}<2 \mu M\right)$ now exists

between where

oxygen decreases

to essentially zero

and where sulfide

starts to increase. search Institute) obtained the nutrient data on Cruises 2, 3, 4 and 5. They utilized a new pump profiling system to obtain exceptionally detailed data through the anoxic interface region. Most scientists involved utilized this system to obtain detailed samples of specific features in the water column.

Preliminary results were presented in December, 1988, at the San Francisco AGU/Ocean Sciences Meeting, and an international conference on the Black Sea is tentatively scheduled for October, 1989 , near İzmir, Turkey.

\section{Preliminary Observations}

A number of observations were made during the 1988 expedition that show that dramatic changes can occur in the oceanographic characteristics of the oxic/anoxic interface of the Black Sea over decadal or shorter time scales. The most exciting of these changes is that the first appearance of sulfide has moved upward in the water column and that a suboxic zone $\left(0_{2}<2 \mu \mathrm{M}\right)$ now exists between where oxygen decreases to essentially zero and where sulfide starts to increase. There are several alternative explanations for these changes that may only be resolvable after all the data from the 1988 expedition are processed.

The general oceanographic characteristics of the Black Sea have been reviewed by Caspers (1957), Sorokin (1983), and in the chapters of the book edited by Degens and Ross (1974). The main features identified in the upper water column were that the surface circulation was anti-clockwise with two or more central gyres, that the surface isohalines were dome shaped and shallower in the central gyres, and that there was a small degree of overlap of oxygen and hydrogen sulfide in the anoxic interface region. Similar data were observed during both the Atlantis II cruise in 1969 and the Chain cruise in 1975, leading to the general impression among U.S. scientists that the anoxic interface region in the Black Sea was a stable feature.

The coexistence of oxygen and hydrogen sulfide has been a subject of detailed investigations. Russian scientists have referred to this zone as the "C-layer" (Sorokin, 1972, 1983). Several recent Russian studies have reported that the upper boundary of the layer was rising and that the $\mathrm{C}$-layer was becoming thicker (Fashchuk and Ayzatullin, 1986; Novoselov, et al., 1987; Leonov and Ayzatullin, 1987). These reports usually are difficult to evaluate because the original data are not published, but it is clear that the Russians have been aware of changes in the oxic/anoxic interface for some time.

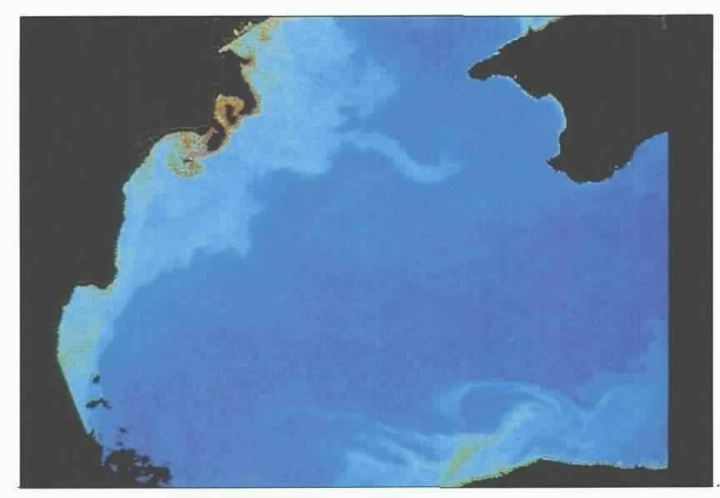

Fig. 1: Sea surface pigment in the western basin of the Black Sea calculated from Coastal Zone Color Scanner (CZCS) data. The lighter colors represent higher pigment concentrations. The northwest shelf region (NWS) is in the upper part of the image. The data on June 22, 1980 were obtained by Gene Feldman (NASA Goddard Space Flight Center) and processed to level 3 relative pigment pattern by Mary Jane Perry and David English (University of Washington).

The new changes in the oxic/anoxic interface region observed during the 1988 expedition can be illustrated using data from Station BS3-2 (the second station occupied during the third cruise). This station was at approximately the same location as Station 1445 of the 1969 Atlantis II cruise (Brewer, 1971). Stations BS3-2 and 1445 will be compared to illustrate the changes. These stations were located in the center of the western basin, which is considered to be a fairly stable region (Fig. 2, p. 17). Because of regional variations, comparisons of this type must be made with stations at the same location.

The changes in the hydrographic properties of the upper $200 \mathrm{~m}$ are shown in Fig. 3 (p. 18). Surface potential temperatures vary because Station 1445 was in April and Station BS3-2 was in June. Otherwise there is excellent agreement in potential temperatures $(\theta)$ below $50 \mathrm{~m}$. The well-defined temperature minimum (bounded by $8^{\circ} \mathrm{C}$ ) centered at $45 \mathrm{~m}$ is the cold intermediate layer (CIL) (Georgiev, 1967; Filippov, 1965). Salinity, on the other hand, is systematically higher from 50 to $200 \mathrm{~m}$ by at least 0.1 ppt. As a result, the density $\left(\sigma_{\theta}\right)$ is now higher by as much as 0.3 units in the $50-200 \mathrm{~m}$ depth range. This has resulted in an upward shift of about $20 \mathrm{~m}$ in the isopycnal surfaces (at this location) relative to 1969 and 1975 data.

The distributions of oxygen and hydrogen sulfide 


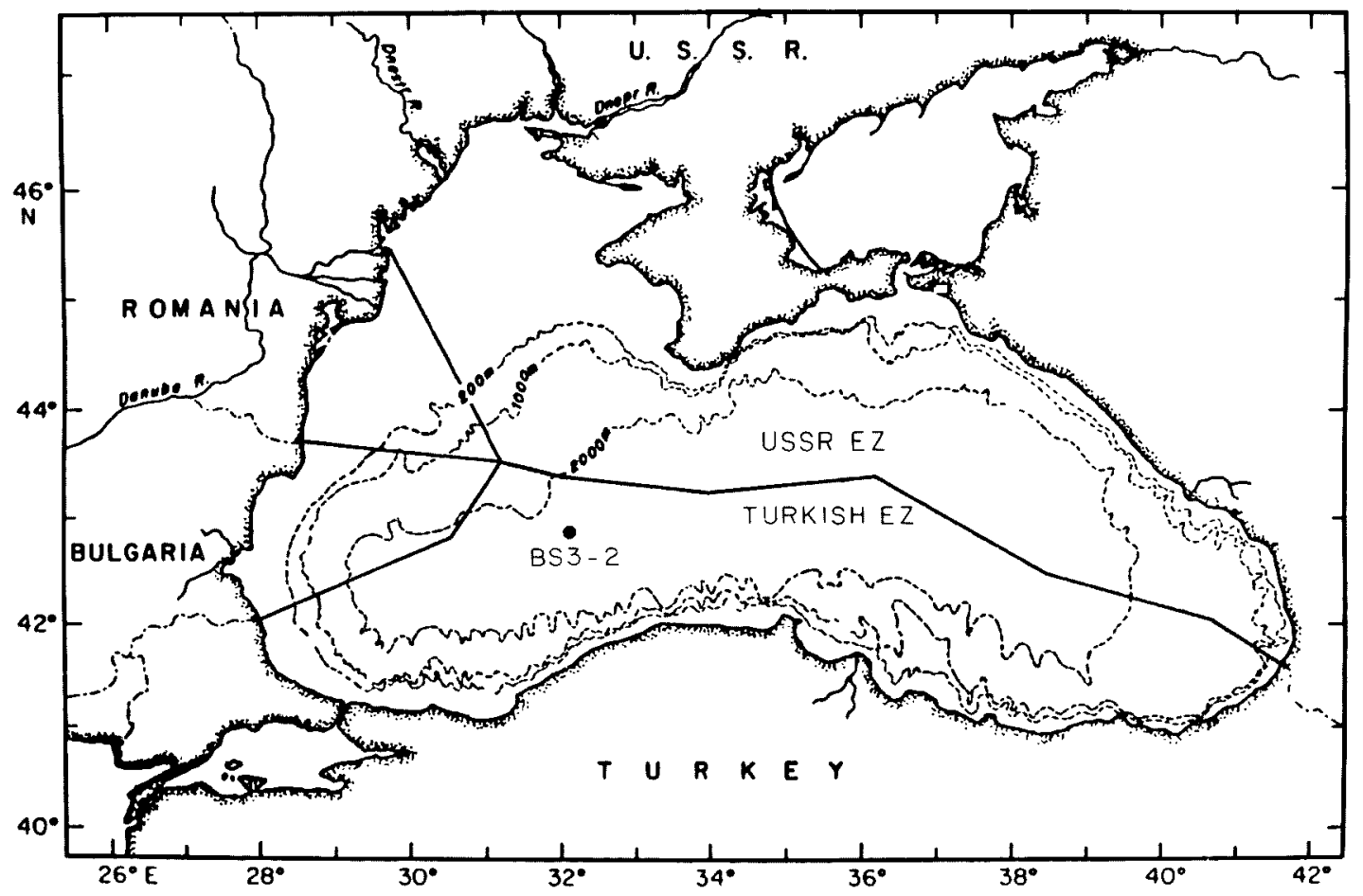

Fig. 2: Chart of the Black Sea showing the boundaries hetween the USSR and Turkish economic zones (EZ). The hydrographic and nutrient data from station BS3-2 are shown in Figures 3,4 and 5. Station 1445 of the 1969 Atlantis II cruise was near station BS3-2. All of the stations occupied during the 1988 Expedition were located in the Turkish EZ.

observed in 1988 at BS3-2 are compared with 1969 data from Atlantis II station 1445 in Fig. 4 (p. 19). The first appearance of sulfide has moved up by about $30 \mathrm{~m}$ from the $\left(\sigma_{\theta}\right)$ density surface of 16.39 to 16.32 . The profiles of the nutrients and total $\mathrm{CO}_{2}$ also show a similar upward shift in the water column (Murray et al.. 1989). In addition a suboxic zone now exists from about $55 \mathrm{~m}$ to $95 \mathrm{~m}$. In this zone the oxygen concentrations are less than $2 \mu \mathrm{M}$ and the hydrogen sulfide concentrations are less than $5 \mathrm{nM}$ (Luther and Church. 1988). This suboxic zone was a surprise because most recent literature has shown an overlap of oxygen and hydrogen sulfide that has been reported to be as large as 90 to $100 \mathrm{~m}$ (Vinogradov, et al., 1986). There is one report by Bol'shakov et al. (1964) of a suboxic zone in a ring structure, apparently caused by unusual mixing conditions; however, this was a rare observation.

The changes in salinity, potential density, oxygen and hydrogen sulfide may reflect the injection of new water into the pycnocline region $(50 \mathrm{~m}$ to $200 \mathrm{~m})$.
Several authors have argued that the pycnocline is maintained by lateral ventilation rather than by onedimensional vertical transport (e.g., Rooth, 1986). Tolmazin (1985) summarized research by himself and others (e.g.. Georgiev, 1967) that argues that the water of the cold intermediate layer originates in the Northwestern Shelf (NWS) region. Ovchinnikov and Popov (1987) have recently argued that the CIL develops at the centers of the cyclonic gyres. Our complete data set may eventually help distinguish between these two alternatives, even though our stations were only located in the Turkish exclusive zone.

Regardless of the origin of the water in the CIL, its density and volume must be linked to the freshwater and heat budgets of the Black Sea. Natural climate variations will have to be determined and taken into account. Superimposed on these natural variations, however. is a reduction in the annual discharge. for agricultural purposes, of some rivers draining from the Soviet Union into the Black Sea. This reduction
This suboxic zone

was a surprise

because most recent

literature has shown an overlap of oxygen and hydrogen sulfide that has been reported to be as large as 90 to $100 \mathrm{~m}$. 
We hypothesize

that intermediate

waters have been

recently (since 1975)

or are now being

injected with a slightly

higher salinity and thus

higher density.

\begin{tabular}{|lcccc|}
\hline \multicolumn{4}{|c}{ Natural } & \multicolumn{3}{c|}{$\%$ Reduction } \\
\hline RIVER & FLOW $\left(\mathrm{km}^{3} \mathrm{yr}^{-1}\right)$ & $1971-1975$ & $1981-1985$ & $\begin{array}{c}1991-2000 \\
\text { (PROUECTEO }\end{array}$ \\
\hline Don & 27.9 & $19 \%$ & $27 \%$ & $43 \%$ \\
Kuban & 13.4 & $39 \%$ & $49 \%$ & $65 \%$ \\
Dnieper & 53.5 & $24 \%$ & $52 \%$ & $71 \%$ \\
Dniester & 9.3 & $20 \%$ & $40 \%$ & $62 \%$ \\
\hline
\end{tabular}

Table 3: Reduction of annual discharge of some rivers draining into the black sea (from Tolmazin, 1985). The total river input into the Black Sea is about $350 \mathrm{~km}^{3} \mathrm{yr}^{-1}$ (Sorokin, 1983).

in fresh water input is summarized in Table 3 (modified from Tolmazin, 1985). Several rivers have been reduced by as much as $50 \%$ and the total river input into the Black Sea has been reduced by about $15 \%$. The projected fresh water diversion for the future is even larger.

Our 1988 observations show that salinity and density are higher in the depth interval of $50 \mathrm{~m}$ to $200 \mathrm{~m}$. The temperature does not appear to have changed. We hypothesize that intermediate waters have been recently (since 1975) or are now being injected with a slightly higher salinity and thus higher density. These waters are being injected at slightly greater depths than in previous years.

Another anoxic basin where mixing events occur on a regular basis is Saanich Inlet on Vancouver Island (e.g., Anderson and Devol, 1973). Sub-oxic zones, similar to the one observed in the Black Sea, are the result (Broenkow, 1969; Emerson, et al., 1982). The flushing events displace anoxic water up in the water column and inject oxygen. Most of the oxygen is consumed by reaction with sulfide and the small amount remaining is consumed by aerobic respiration. The mixing event hypothesis provides a unifying explanation for the changes in salinity, density, oxygen and hydrogen sulfide. The exact timing and depth of such mixing events in the Black Sea may be determined from analyses of tracers, such as the chlorofluorocarbons (Bullister, 1988), Chernobyl isotopes (Buesseler and Livingston, 1988), and carbon 14 and tritium (Top, 1988).

If the reduction in fresh water flow from Russian rivers is the cause of these changes, there is reason to

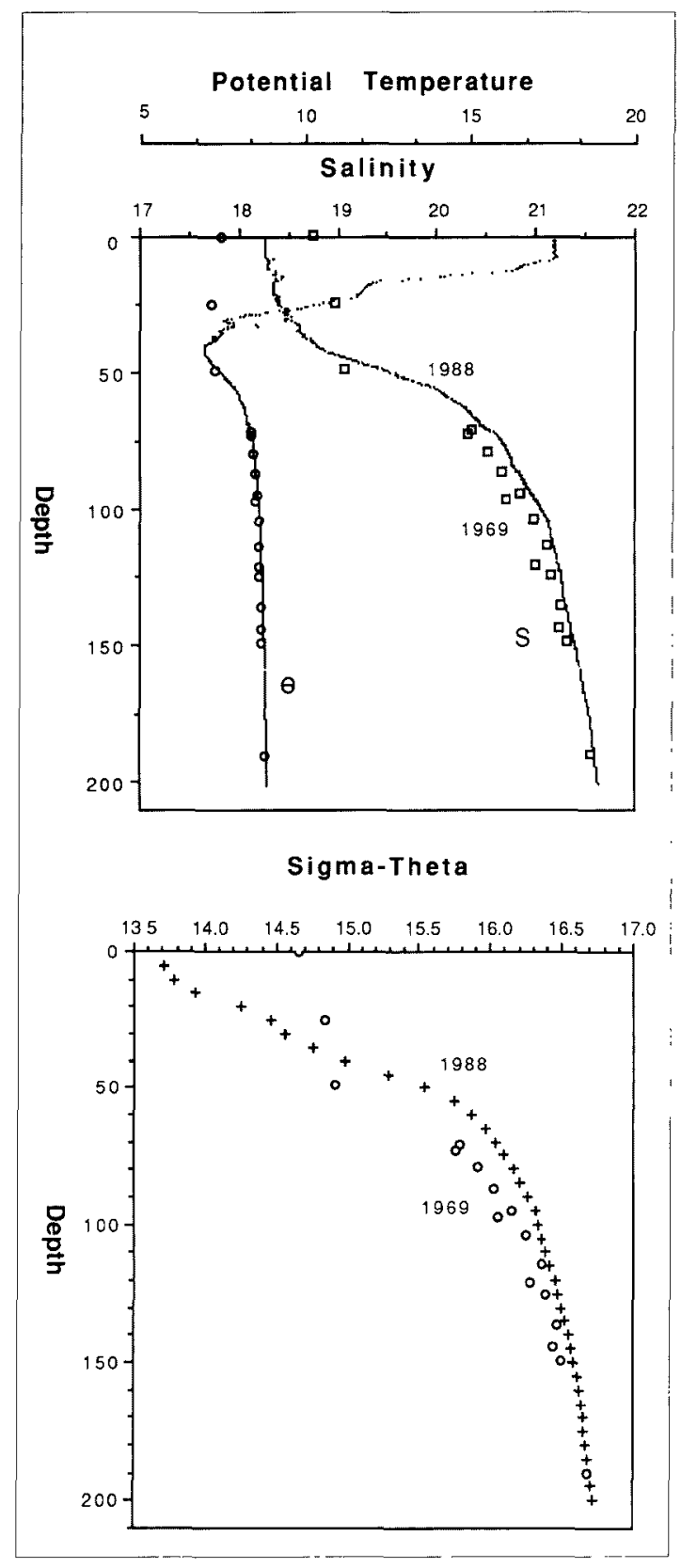

Fig. 3: Potential temperature, salinity and density versus depth $(m)$ in the central part of the western basin of the Black Sea (after Murray et al., 1989). The open symbols are from station 1445 of the 1969 Atlantis II Black Sea cruise. Closed symbols are from station BS3-2 of cruise 3 of the U.S.- Turkish Expedition (June, 1988). Upperpanel:Potential temperature $(\theta)$ and salinity $(S)$; Lower panel: Potential density $\left(\sigma_{\theta}\right)$ 


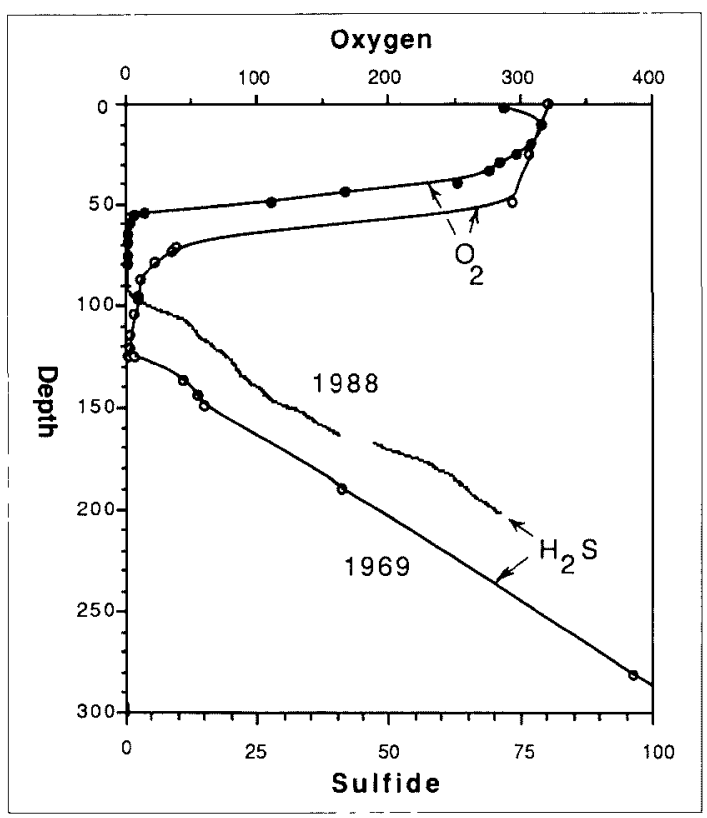

Fig. 4: Oxygen $\left(\mathrm{O}_{2}\right)$ and hydrogen sulfide $\left(\mathrm{H}_{2} \mathrm{~S}\right)$ versus depth $(m)$. Open symbols are from Atlantis II station 1445 (1969). Closed symbols (for $\mathrm{O}_{2}$ ) and the nearly continuous curve (for $\mathrm{H}_{2} \mathrm{~S}$ ) are from station BS3-2 of the Turkish expedition. For both $\mathrm{O}_{2}$ and $\mathrm{H}_{2} \mathrm{~S}$, the upper curve shows 1988 data, and the lower curve shows 1969 data. All units are $\mu$ mol kg ${ }^{-1}$ (After Murray et al., 1989)

expect that the possibility for continuing change exists. The worst case would be if mixing events, as hypothesized above, were to mix hydrogen sulfide water to the surface, creating a major ecological catastrophe. A monitoring program should be implemented to document future changes.

The nitrogen cycle appears to be extremely active in the suboxic zone. Nitrate increases rapidly from below detection at $35 \mathrm{~m}$ to a maximum of about $8 \mu \mathrm{M}$ at $55 \mathrm{~m}$ (Fig. 5). This is the same depth at which oxygen goes to suboxic values (Fig. 4). Nitrate decreased rapidly within the suboxic zone and reached zero significantly above the first appearance of sulfide. At station BS3-2, nitrite maxima occurred near the top and bottom of the nitrate maximum, reflecting nitrite's role as an intermediate in both nitrification and denitrification, and ammonia increased rapidly below $75 \mathrm{~m}$. With regard to the entire Black Sea data set, the deeper maximum was usually larger, and it occurred more frequently than the shallower maximum. At some stations multiple maxima occurred.

The phosphate profile is interesting because it

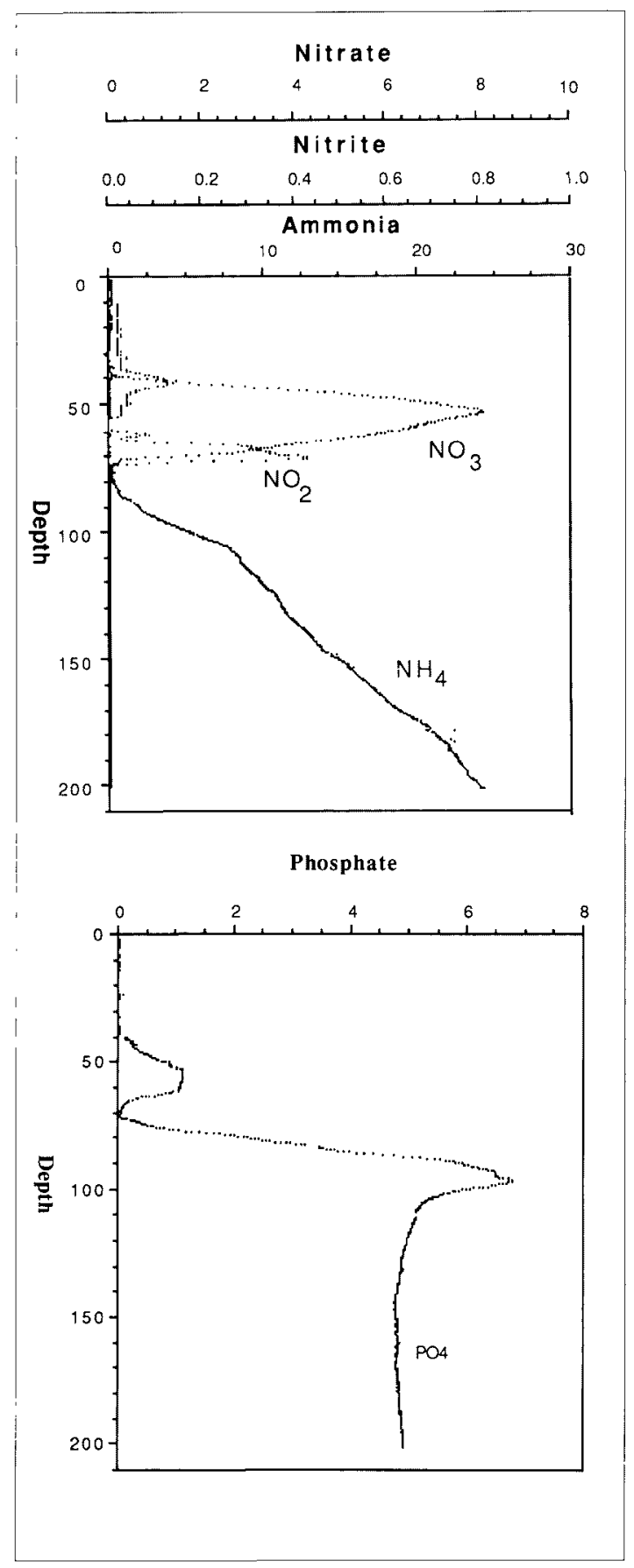

If the reduction

in fresh water flow from Russian rivers is the cause of these changes, there is reason to expect that the possibility for continuing change exists.
Fig. 5: Nutrient profiles in the upper water column (to 200m) at station BS3-2. Data are from the pump profiling system operated by G. Friederich (Monterey Bay Aquarium Research Institute). All concentrations are in $\mu$ mol $\mathrm{kg}^{-1}$. Upper panel: nitrate $\left(\mathrm{NO}_{3}\right)$, nitrite $\left(\mathrm{NO}_{2}\right)$ and ammonia $\left(\mathrm{NH}_{4}\right)$; Lower panel: phosphate $\left(\mathrm{PO}_{4}\right)$ 
The oxic/anoxic

interface in the Black

Sea is a nutrient trap. shows a maximum at $55 \mathrm{~m}$, decreasing to essentially zero at $70 \mathrm{~m}$, and then increasing rapidly to a large maximum at $95 \mathrm{~m}$ (Fig. 5). The upper $\mathrm{PO}_{4}$ maximum is probably due to release of organic matter during aerobic respiration. The minimum and deeper maximum probably reflect the involvement of $\mathrm{PO}_{4}$ in the Mn and Fe cycles (Murray et al., 1989).

There are significant questions about the chemical distributions around the suboxic zone that will need to be reconciled with the microbiological distributions. For example, one major question that arises from the distributions in Fig. 4 is what is oxidizing the sulfide? Both oxygen and nitrate reach low concentrations above the first appearance of sulfide. Dissolved Mn and Fe increase rapidly with the sulfide, suggesting that sulfide oxidation is coupled with metal oxide reduction. Reduced $\mathrm{Mn}(\mathrm{II})$ and ammonia decrease to low values at the same depth as nitrate. This depth is significantly below where oxygen decreases to suboxic values. These distributions suggest that $\mathrm{Mn}(\mathrm{II})$ and ammonia are being oxidized by nitrate. While these reactions may be thermodynamically favorable, it is not clear that they can yield enough energy to be biologically advantageous. Experiments by Tebo (1988) suggest that the oxidation of $\mathrm{Mn}(\mathrm{II})$ is biologically catalyzed.

Finally, we would like to point out that the oxic/ anoxic interface in the Black Sea is a nutrient trap. The strong minimum in phosphate at $70 \mathrm{~m}$ indicates that it is efficiently removed at that depth. probably by adsorption on solid metal oxides, and returned to the deep water. Similarly, all fixed nitrogen species have steep gradients converging to zero at $75 \mathrm{~m}$, suggesting that nitrogen is efficiently removed removed at that depth. Thus new primary production in the Black Sea must be supported by nutrients supplied from the atmosphere and rivers.

\section{Summary}

The 1988 Black Sea Expedition was a great success. There was a high degree of collaboration between scientists of many disciplines. It was truly an international expedition in which especially the Turkish oceanographers played a major role in the planning and execution of the five cruises.

The preliminary results show that major changes have occurred in the hydrographic, oxygen and hydrogen sulfide distributions. The first appearance of sulfide has moved to shallower depths, and a suboxic zone with low oxygen and hydrogen sulfide now exists. These changes are consistent with the hypothesis that shallow intermediate water has recently formed with a slightly higher salinity, and thus density, than in previous years. It will be important to resolve whether these changes are due to decadalscale variations in climate, or to the diversion of freshwater input from Russian rivers.

The chemical and microbiological distributions above and below the suboxic zone point to many questions that should be resolvable by research in progress on the Black Sea samples. In the end we should have greatly increased our understanding of anoxic systems.

\section{Acknowledgements}

The success of this expedition was largely due to the help and assistance of the captain. bosun and crew of the R/V Knorr; George White. Mike Recasner and Jim Postel worked long hours to ensure everyone got the samples they wanted and to acquire the hydrographic data. Gernot Friederich and Lou Codispoti were responsible for the nutrient data. This contribution sponsored by NSF grant OCE 861440. University of Washington contribution number 1798 .

\section{References}

Anderson. J.J. and A.H. Devol. 1973: Deep water renewal in Saanich Inlet, an Intermittently Anoxic Basin. Est. Coust. Mar. Sot., I, 1-10.

Bol'shakov, V.S., D.M.Tolmazin and M.Sh. Rozengurt, 1964 : The horizontal circulation in the Black Sea. Isvetia Acad $S$ i. . 6. 562-565.

Brewer. P.G., 1971: Hydrographic and chemical data from the Black Sea. Woods Hole Oceanographic Institution, Tec. No. 71-65.

Broenkow, W.W.. 1969: The distribution of non-conservative solutes related to the decomposition of organic material in anoxic marine basins. Ph.D. Thesis, University of Washington. 207pp.

Buesseler, K.O. and H.D. Livingston, 1988: Studies of Chernobyl radionuclides in the Black Sea. EOS, 69, 1241.

Bullister. J.L., 1988: Chlorofluorocarbon studies in the Black Sea. EOS. $69,1239$.

Caspers, H., 1957: Black Sea and Sea of Azov. Geol Sre Amer Me'm. 67. 8(1.3-890).

Degens, E.T. and Ross. D.A., 1974: The Black Sea geology. chemistryand bology. American Association of Petroleum Geologists. Tulsa, 635pp.

Emerson, S.. S. Kalhorn, L. Jacobs. B.M. Tebo, K.H. Nealson and R.A. Rosson, 1982: Environmental oxidation rate of manganese(II): Bacterial catalysis. Goochim. Cosmochim. Acta, 46, 1073-1079.

Fashchuk. D. Ya. and T.A. Ayzatullin. 1986: A possible transformation of the anaerobic zone of the Black Sea. Oreanology, 26. 171-178

Filippov, D.M. 1965: The cold intermediate layer in the Black Sea. Oceunology. 5, 47-52.

Georgiev, Yu. S., 1967: On dynamics of cold intermediate layer in the Black Sea. In: Okeanugraficheskive issledovaniva Chernogo Morva (Ocedungraphe Investigattoms of the Black Se(l). Naukova Dumka, Kiev, $105-113$ (Russian).

Leonov, A.V. and T.I. Ayzatullin, 1987: Mathematical modeling of the oxtdation of hydrogen sulfide in connection with calculations of the dynamics of the hydrogen sulfideoxygen coexistence layer and process conditons for obtaining sulfur from Black Sea water. Occunology. 27. 174-178.

Luther. G.W. and T.M. Church, 1988: Sulfur speciation and possible sulfide oxidation in the water column of the Black Sea. EOS. 69.1242.

Murray, J.W. H.W. Jannasch. S. Honjo, R.F. Anderson, W.S Reeburgh. 7. Top. G.E. Friederich. L.A. Codispoti. and E. 
Izdar, 1989: Unexpected changes in the oxic/anoxic interface in the Black Sea. Nature, 337 (in press).

Novoselov. A. A., Ye. Ye. Sovga, D. Ya. Fashchuk. S.M. Khomutov and A.I. Sheremet yeva. 1987: Comparative evaluation of the iodometric and fluorimetric methods of determining hydrogen sulfide in the layer of its coexistence with oxygen in the Black Sea. Oceanology. 27, 304-307.

Ovchimikov, I.M. and Yu. I. Popov, 1987: Evolution of the cold intermediate layer in the Black Sea. Occanology, 27, 555560 .

Rooth, C.G.H., 1986: Comments on circulation diagnostics and implications for chemical studies of the Black Sea. Report on the Chemistry of Seawater, XXXII, Univ Goteborg, Sweden.

Sorokin. Yu, I. 1972: The bacterial population and the processes of hydrogen sulfide oxidation in the Black Sea. J. Cons. Int. Explor. Mer.. 34. 423-454.

Sorokin. Yu, I., 1983: The Black Sea. In: Estuaries and enclosed scas. Ecosystems of the world. B.H. Ketchum, editor, Elsevier. Amsterdam. 26. 253-292.

Tcho, B.M. 1988: Manganese oxidation at the oxygen/hydrogen sulfide interface in the Black Sea. EOS. 69. 1105.

Tolmazin. D.. 1985: Changing coastal oceanography in the Black Sea. 1: Northwestern Shelf. Prog Oceanog.. 15. 217-276.

Top. Z.. 1988: Summary of preliminary results from the Black Sea--leg 4 -Tracer Chemistry, EOS, 69, 1230.

Vinogradov, M.Ye., E.A. Shushkina, M.V. Flint and N.I. Tumantsev, 1986: Plankton in the lower layers of the oxygen zone in the Black Sea. Oceanology, 26, 222-228.

Table 1: Organizing Committee For the 1988 Black Sea Oceanographic Expedition

- Earl İzdar. Turkish Charman, Dokuz. Eylül University. İzmir, Turkey

- Turgut Balkas, Middle East Technical University, Ankara, Turkey

- IImit Unluata, Middle East Technical University. Erdemli, Turkey

- James Murray. U.S. Charman. University of Washington, Seattle, Washington

- Susumu Honjo. Woods Hole Oceanographic Institution, Woods Hole. Massachusetts

- Holger Jannasch, Woods Hole Oceanographic Institution.

Woods Hole. Massachusetts

- Neil Andersen, Ex. Officio, National Science Foundation. Washington, D.C.

Table 2: Scientific Projects, 1988 Black Sea Oceanographic Expedition

Cruise I

- Sediment trap deployment and recovery (Hay. Honjo, Konuk,

Kempe, Liebezeit. Nicholson and Woodward)

- Total suspended matter (Woodward)

- Sulfur fluxes (Nicholson)

- Mini-Rover observations (Diercks, Kempe)

- In-situ pumping at the Mn rich layer (Kempe, Diercks)

- Plankton community identification (Pilskaln, Berli)

- Marne snow (Asper)

- Sediment fluf layers (Honjo. Broda, Pilskaln)

- Porewater analysis (Liebezeit)

- Coring and sediment processing, $x$-radiography, stratigraphy, lithology and paleo-oceanography, ${ }^{14} \mathrm{C}$ chronology, (Arthur. Broda, Dean, Derman, Gagnan, Hay, Konuk, Honjo, Neff, Pilskaln, and Briskin!

Crutse?

- Microbial transformations in the oxic/anoxic interface. Rates of chemosynthests, "C-tracer studies, enumeration of microrganisms, isolation of sulfur-oxidizing and reducing bacteria (Jannasch. Wirsen Molyneaux)

- Denitrification (Bazylinski)

- Production and cycling of organic carbon, photosynthesic productivity, floating sediment traps (Karl, Knauer)

- Sulfur cycling (Jorgensen, Fossing)

- Bacterial sulfate-reduction in the water column, fluff layer and surface sediments (Taylor, Mlodzinska, Doherty, Albert and Canuel)

- Enrichment and isolation of sulfate-reducing bacteria (Cypionka)

- Organic chemistry-pigment analyses (Repeta, Simpson)

- Stable isotope studies (C, N and S) (Fry)

Cruise 3

- Trace metal distributions (dissolved, particulate and speciation) $\mathrm{Mn}, \mathrm{Fe}, \mathrm{Cr}, \mathrm{Ni}, \mathrm{Co}, \mathrm{Cu}, \mathrm{Cd}, \mathrm{Pb} ; \mathrm{Mo}$ and $\mathrm{V}$ for $\mathrm{S}$. Emerson; Te and Bi for D.S. Lee; Sc and Ti for K. Orians (Landing, Lewis). Ge. Se, As, Sb; REE for Klinkhammer (Froelich, Cutter. Mortlock)

- Scavenging isotopes ${ }^{334} \mathrm{Th},{ }^{231} \mathrm{Th},{ }^{22 x} \mathrm{Th},{ }^{211} \mathrm{~Pa},{ }^{210} \mathrm{~Pb},{ }^{211} \mathrm{Po}$; ${ }^{16} \mathrm{Be}$ and ${ }^{~} \mathrm{Be}$ for T.L.Ku; " ${ }^{21} \mathrm{Th}$ for C.A. Huh; ${ }^{22 k} \mathrm{Ra}$ and ${ }^{22 *} \mathrm{Ra}$ for D.O'Neill (Wei. Paul, Murray).

- Floating sediment traps, trace metal and scavenging isotope fluxes (Jannasch. Murray).

- Sulfur speciation (Luther, Church)

- Dissolved inorganic carbon, total $\mathrm{CO}_{2}$. alkalinity (Goyet, Bradshaw)

- $\mathrm{MnO}{ }_{2}$ reductuon and microbiology (Nealson, Russon)

- Mn(II) oxidation (Tebo. Troutman)

- Pore water nutrients and metals (Froelich, Cutter, Landing)

- Golden Horn sediment cores (Tuncel, Toksoz)

- Atmospheric particulate metals (Tuncel, Hacisalihoglu)

Cruise 4

- Water column tracers of circulation and mixing: ${ }^{14} \mathrm{C}$, tritium. $\mathrm{He}$ isotopes, noble gases (Top, Oleson): $\delta^{1 \times} 0, \mathrm{D} / \mathrm{H}$ (Swart); ${ }^{22 n} \mathrm{Ra}$,

${ }^{22} \mathrm{Ra}, \mathrm{Ba}\left(\mathrm{O}^{\wedge} \mathrm{Neill}\right)$; Freons (Bullister, Ozsoy): Chemobyl isotopes, ${ }^{1{ }^{27} \mathrm{Cs},{ }^{14} \mathrm{Cs},{ }^{234}, 241} \mathrm{Pu},{ }^{106} \mathrm{Ru},{ }^{144} \mathrm{Ce}$ and ${ }^{147} \mathrm{Pm}$ (Buesseler, Hartman) ${ }^{89} \mathrm{Tc},{ }^{278} \mathrm{Pu},{ }^{239},{ }^{2411} \mathrm{Pu},{ }^{177} \mathrm{Cs}$ (Portakal); Plutonium isotopes and oxidation states (Sanchez)

- Sediment geochemistry: Pore water chemistry-nutrients and metals (Balci, Lyons, Anderson, Calvert); Pore water Mo and V (Stump): Pore water/solid sediment uranium (Anderson, Barnes); Major and minor element geochemistry, ${ }^{14} \mathrm{C}$ chronology (Calvert); Organic matter sources and reactivity (Cowie); Magnetic susceptibility and sediment diagenesis (Karlin): Pyrite formation; oxic versus anoxic deposition (Lyons)

Cruise 5

- Anaerobic methane oxidation; methane concentrations, aerobic and anaerobic methane oxidation rates, sulfate reduction rates in sediments, $\delta^{13} \mathrm{C}$ and $\mathrm{D} / \mathrm{H}, \mathrm{S}^{\mathrm{n}}$ turnover experiments (Reeburgh. Whalen, Sandbeck, Basturk)

- Nitrogen cycling: assimilation of $\mathrm{NO}_{3}, \mathrm{NO}_{2}$, and $\mathrm{NH}_{4}$, oxidation of $\mathrm{NH}_{4}$ and $\mathrm{NO}_{2}$, reduction of $\mathrm{NO}_{3}$, particulate nitrogen, $\delta^{15} \mathrm{~N}, \mathrm{~N}_{2} 0$ and $\mathrm{NH}_{2} \mathrm{OH}$ for J. Butler; Methane oxidation rates: Primary production, chlorophyll profiles (Ward, Kilpatrick, Kerkhof, Gucu)

- Low molecular weight carbonyls, amino acids, thiols, fatty acids, flavins, proteins. carbohydrates and humic substances (Mopper, Kieber, Basturk)

- Sulfide oxidation rates, concentration of sulfur intermediates

(Millero)

- Aerobic methane oxidation (Remsen, Buchholz)

- Flavins, fluorescence and microbial activity (Garfield, Christensen)

- Organic geochemistry-lipids (Wakeham, Clifford)

- Rare earth elements, ${ }^{14} \mathrm{Nd} /{ }^{144} \mathrm{Nd},{ }^{1+4} \mathrm{Ce}$ and ${ }^{1+7} \mathrm{Pm}$ (deBaar)

- Marine snow distribution and flux (Asper)

- Time series sediment trap recovery (Asper) 